\title{
Influence of Adjunct Use and Cheese Microenvironment on Nonstarter Bacteria in Reduced-Fat Cheddar-Type Cheese ${ }^{1}$
}

\author{
J. R. Broadbent, ${ }^{\star}$ K. Houck, † M. E. Johnson,† and C. J. Oberg‡ \\ *Western Dairy Center and Department of Nutrition and Food Sciences, \\ Utah State University, Logan, 84322-8700 \\ tWisconsin Center for Dairy Research, \\ University of Wisconsin, Madison, 53706 \\ $\ddagger$ Department of Microbiology, \\ Weber State University, Ogden, UT 84408-2506
}

\section{ABSTRACT}

This study investigated population dynamics of starter, adjunct, and nonstarter lactic acid bacteria (NSLAB) in reduced-fat Cheddar and Colby cheese made with or without a Lactobacillus casei adjunct. Duplicate vats of cheese were manufactured and ripened at $7^{\circ} \mathrm{C}$. Bacterial populations were monitored periodically by plate counts and by DNA fingerprinting of cheese isolates with the random amplified polymorphic DNA technique. Isolates that displayed a unique DNA fingerprint were identified to the species level by partial nucleotide sequence analysis of the $16 \mathrm{~S}$ rRNA gene. Nonstarter biota in both cheese types changed over time, but populations in the Colby cheese showed a greater degree of species heterogeneity. The addition of the $L$. casei adjunct to cheese milk at $10^{4} \mathrm{cfu} / \mathrm{ml}$ did not completely suppress "wild" NSLAB populations, but it did appear to reduce nonstarter species and strain diversity in Colby and young Cheddar cheese. Nonetheless, nonstarter populations in all 6-mo-old cheeses were dominated by wild $L$. casei. Interestingly, the dominant strains of $L$. casei in each 6-mo-old cheese appeared to be affected more by adjunct treatment and not cheese variety.

(Key words: Lactobacillus, nonstarter lactic acid bacteria, cheese flavor)

Abbreviation key: NSLAB = nonstarter lactic acid bacteria, RAPD = randomly amplified polymorphic DNA.

\section{INTRODUCTION}

Flavor development in Cheddar and other bacterialripened cheeses is a dynamic and complex biochemical

Received October 18, 2002.

Accepted February 26, 2003

Corresponding author: J. R. Broadbent; e-mail: broadbnt@ cc.usu.edu.

${ }^{1}$ This research was supported by the Utah Agricultural Experiment Station, Utah State University, Logan, 84322-4810. Approved as Journal Paper Number 7489. process that requires lactic acid bacteria and enzymes (Reiter et al., 1967; Fox et al., 1993). The lactic acid bacteria that contribute to this process include deliberately added starter and adjunct cultures, as well as nonstarter lactic acid bacteria (NSLAB) that enter cheese through milk or via contamination of the dairy plant environment (Peterson and Marshall, 1990; Beresford et al., 2001; Somers et al., 2001). In Cheddar cheese, initial numbers of Lactococcus lactis starter bacteria frequently exceed $10^{9} \mathrm{cfu} / \mathrm{g}$, but the harsh cheese ripening environment (no residual lactose, $\mathrm{pH} 5.0$ to $5.3,4$ to $6 \%$ salt in moisture, 5 to $13^{\circ} \mathrm{C}$ ) causes starter viability to decline as maturation proceeds. A fraction of the dying starter cells undergo autolysis, which releases intracellular enzymes and cellular components (e.g., sugars and nucleic acids) into the cheese matrix (Fryer, 1969). At the same time, NSLAB populations (whose initial numbers are typically below $10^{3} \mathrm{cfu} / \mathrm{g}$ ) begin to grow and eventually plateau at cell densities of $10^{7}$ to $10^{9} \mathrm{cfu} / \mathrm{g}$ after 3 to 9 mo of aging (Peterson and Marshall, 1990). The NSLAB population in Cheddar-type cheese is typically dominated by mesophilic, facultatively heterofermentative lactobacilli (Sherwood, 1939; Fryer, 1969; Peterson and Marshall, 1990; Beresford et al., 2001). Use of Lactobacillus spp. NSLAB isolates as adjunct cultures for Cheddar cheese manufacture has indicated these bacteria may influence flavor in at least three ways: they may intensify (i.e., accelerate) typical flavor development; impart atypical (but desirable) flavor notes; or promote off-flavor development (Sherwood, 1939; Fryer, 1969; Broome et al., 1990b; McSweeney et al., 1994; Lynch et al., 1999; Crow et al., 2001; Swearingen et al., 2001). In addition, NSLAB can produce cheese quality defects such as open body (via gas production) and calcium lactate crystals (Fryer, 1969; Johnson et al., 1990). Because starter and NSLAB can each influence overall cheese quality, industry efforts to produce more uniform, flavorful products will require technologies to control both populations of bacteria.

While the types and numbers of starter (or adjunct) bacteria in cheese can be readily controlled, the com- 
plexity of NSLAB populations is still largely a matter of chance. The NSLAB biota of cheese is influenced by several factors including process and equipment sanitation in the manufacturing plant and milk heat treatment (Fox et al., 1998; Berthier et al., 2001; Somers et al., 2001). Several studies have demonstrated that substantial heterogeneity exists in the ratio of species and strains that dominate in a given cheese, even between products made in the same processing facility (Sherwood, 1939; Naylor and Sharpe, 1958; Jordan and Cogan, 1993; Williams and Banks, 1997; Fitzsimons et al., 1999 and 2001; Crow et al., 2001; Swearingen et al., 2001). Moreover, a succession of different Lactobacillus spp. and strains may dominate the NSLAB biota of Cheddar cheese at various stages of ripening (Crow et al., 2001; Fitzsimons et al., 2001).

Because the impact of NSLAB on cheese flavor is ultimately determined by the metabolic activities of bacteria that predominate during ripening, individual strains may, in theory, have a profound effect on cheese flavor and body characteristics (Williams et al., 2000). The unpredictable and dynamic nature of NSLAB communities is, therefore, believed to be an important source of cheese flavor defects and inconsistencies (Sherwood, 1939; Crow et al., 2001). If this hypothesis is correct, stringent control of NSLAB populations during ripening should facilitate industry efforts to produce more uniform, high-quality cheese.

One strategy to accomplish this goal is the use of Lactobacillus adjunct cultures that grow in ripening cheese (but do not affect the manufacturing process), possess desirable flavor-producing attributes (or at least have no negative effect on flavor), and suppress the emergence of "wild" NSLAB (Broome et al., 1990a; Crow et al., 2001). Although efforts to enhance flavor development with NSLAB adjuncts have produced mixed results (Peterson and Marshall, 1990), the overall efficacy of this approach is supported by academic studies that showed some adjuncts dominated wild NSLAB counterparts during ripening of Cheddar cheese (Broome et al., 1990b; Crow et al., 2001; Ryan et al., 2001; Swearingen et al., 2001). Furthermore, adjunct addition may help to control culture-related cheese quality defects (Layele et al., 1990; FrohlichWyder et al., 2002). Although adjuncts offer good promise as a tool to control cheese NSLAB and improve cheese quality, the dynamic environment of ripening cheese and the variability imparted by differences in cheese composition, added cultures or enzymes, and manufacturing or ripening regimens, suggests NSLAB control may be a difficult goal. Thus, industry efforts to utilize adjunct technology for NSLAB control would profit from a more fundamental understanding of the relationship between cheese environment, adjunct use, and NSLAB population dynamics.

Among the specific protocols used to make cheeses, curd washing or whey dilution steps offer the potential to produce dramatic differences between cheese varieties. Colby cheese is a washed, stirred-curd variety of Cheddar, and both cheeses are commonly manufactured with identical strains of Lc. lactis starter. In Colby manufacture, cold water is added to the curd after most of the whey has been drained. The wash treatment serves two purposes; it removes lactose and lactic acid from the curd, and cools the curd. Removal of lactic acid and lactose gives the finished cheese a lower acid content and a slightly higher $\mathrm{pH}$. Cooling produces a slight increase in cheese moisture content and an initially firmer curd, which in turn produces a more open texture (Johnson, 2001). Whereas Cheddar can be aged for years, Colby is typically consumed within 3 mo since more aged Colby develops a pasty body and is often accompanied by undesirable flavor development.

Although differences in the flavor or flavor intensity of washed versus nonwashed (but otherwise identically produced) cheeses are commonly noted, the basis for this observation is unknown. One widely accepted theory is that the environment of washed curd cheese is not conducive to the development of particular flavor compounds, but many cheese technologists also believe that the changes in acid content and $\mathrm{pH}$ somehow alter cheese microbiology. In this study, we investigated NSLAB population dynamics in reduced-fat Cheand Colby cheese, and examined the effect of a $L b$. casei adjunct on NSLAB populations.

\section{MATERIALS AND METHODS}

\section{Bacterial Strains}

Lactococcus lactis ssp. cremoris SCO213 was acquired from Chr. Hansen, Inc. (Milwaukee, WI) and propagated at $30^{\circ} \mathrm{C}$ in M17 broth (Difco, Beckton Dickinson, Sparks, MD). The adjunct, L. casei LILA, was obtained from the Wisconsin Center for Dairy Research culture collection and grown at $30^{\circ} \mathrm{C}$ in MRS broth (Difco). Stocks of each culture were maintained at $-80^{\circ} \mathrm{C}$, and working samples were prepared from frozen stocks by two transfers in broth medium.

\section{Cheese Manufacture}

Duplicate vats of $50 \%$ reduced-fat Cheddar and Colby cheese were manufactured at the University of Wisconsin-Madison from 250-kg lots of pasteurized milk (1.3\% fat). The milk was inoculated with $1 \%$ Lc. lactis ssp. cremoris $\mathrm{SCO} 213$ starter grown at $30^{\circ} \mathrm{C}$ for 12 to $14 \mathrm{~h}$ 
in steamed $\left(88^{\circ} \mathrm{C}\right.$ for $\left.45 \mathrm{~min}\right)$ skim milk. An additional set of duplicate vats for each cheese type was inoculated with starter plus $4 \mathrm{ml}$ of $L b$. casei LILA ( $\left.10^{8} \mathrm{cfu} / \mathrm{ml}\right)$.

Fifteen minutes after starter addition, $49 \mathrm{ml}$ of calcium chloride (Rhodia, Inc., Madison, WI) and $19 \mathrm{ml}$ of double-strength fermentation-produced chymosin (Chr. Hansen, Inc., Milwaukee, WI) were added. The coagulum was cut at a milk $\mathrm{pH}$ of 6.5 with 0.95 -cm knives and allowed to heal for $5 \mathrm{~min}$. After $10 \mathrm{~min}$ of gentle agitation, the temperature of the curd and whey slurry was raised from $32^{\circ} \mathrm{C}$ to $37.8^{\circ} \mathrm{C}$ over $25 \mathrm{~min}$, then the whey was slowly drained. Curd for the manufacture of Cheddar was formed into slabs, cheddared, then milled when the curd reached pH 5.95. Fifteen minutes after milling, curd for Cheddar cheese manufacture was salted in three additions, 5 min apart, with $0.275 \%$ (wt/ wt) flake salt (calculated from the original milk weight). For the manufacture of Colby, the curd was washed with $32^{\circ} \mathrm{C}$ water for 15 min before salt addition $(\mathrm{pH}$ 5.86). After salt addition, the curd was packed into 9$\mathrm{kg}$ rectangular stainless steel hoops, pressed for $4 \mathrm{~h}$ at ambient temperature, vacuum-packaged, and stored at $7^{\circ} \mathrm{C}$ for ripening. Cheese $\mathrm{pH}$, fat, moisture, salt, and lactic acid contents were determined as described previously (Weimer et al., 1997).

\section{Microbiological Sampling}

In an effort to identify possible sources of cheese NSLAB, microbiological surface samples were collected as described by Somers et al. (2001) immediately before cheese manufacture from inside and outside of cheese vats, floor drains between vats, cheese mill, lab benches, milk lines, and from the stirrer motor. Samples were also collected from pasteurized (uninoculated) cheese milk, then appropriate dilutions were plated on Elliker's and Rogosa SL agars (Difco) and incubated for 2 $\mathrm{d}$ at $30^{\circ} \mathrm{C}$.

Microbiological sampling of experimental cheese was performed at d 1,2 wk, and once per month thereafter. Cheese samples (approx. $20 \mathrm{~g}$ ) were collected, homogenized in sterile $2 \%$ sodium citrate $\left(45^{\circ} \mathrm{C}\right)$ using a Seward (London, UK) model 400 Stomacher, then total bacterial counts were enumerated by the pour plate method with Elliker agar. Nonstarter and adjunct lactobacilli numbers were determined using Rogosa SL agar. Plates were incubated anaerobically for $2 \mathrm{~d}$ at $32^{\circ} \mathrm{C}$ (Elliker agar) or $37^{\circ} \mathrm{C}$ (Rogosa agar), and numbers of starter cfu were determined by subtracting the Lactobacillus ssp. count from the total bacterial count.

\section{DNA Fingerprinting of Bacteria}

Twenty isolates were selected at random from Rogosa and Elliker plates (10 per plate) collected from each cheese for microbiological counts at d 1 , and at 2,4 , and 6 mo of ripening, and propagated overnight in their respective broth media. Frozen stock samples were prepared in quadruplicate by addition of $0.2-\mathrm{ml}$ overnight culture to $1.8 \mathrm{ml}$ of $9 \%$ reconstituted skim milk with $17 \%$ glycerol, then stored at $-80^{\circ} \mathrm{C}$ in $2-\mathrm{ml}$ cryotubes. Template DNA for PCR was isolated from $250 \mu \mathrm{l}$ of the overnight culture as described previously (Broadbent et al., 1998) and stored at $-80^{\circ} \mathrm{C}$ until needed.

Randomly amplified polymorphic DNA (RAPD) fingerprinting (Bassam et al., 1992) was used to investigate NSLAB population dynamics during ripening. The RAPD was performed in $25-\mu \mathrm{l}$ reaction volumes that contained $2.5 \mathrm{mM} \mathrm{Mg}{ }^{2+}, 0.4 \mathrm{~m} M$ dNTP blend, $1 \mathrm{U}$ Taq DNA polymerase (Invitrogen, Carlsbad, CA), $4 \mu M$ oligonucleotide primer (5'-TCAGCAGCCGCGG TAATTC$3^{\prime}$ ), and $4 \mu \mathrm{l}$ of template DNA. Negative controls were prepared with sterile water as a substitute for template DNA. Samples were overlaid with $30 \mu \mathrm{l}$ of PCR-grade sterile mineral oil (Perkin Elmer, Foster City, CA), then 40 PCR cycles were run in a Perkin-Elmer DNA Thermal Cycler model 480 set to the following parameters: denaturation at $94^{\circ} \mathrm{C}$ for $1 \mathrm{~min}$, annealing for $1 \mathrm{~min}$ at $38^{\circ} \mathrm{C}$, and extension at $72^{\circ} \mathrm{C}$ for $2 \mathrm{~min}$. When the cycles were complete, the reaction was finished by incubation at $72^{\circ} \mathrm{C}$ for 5 min then stored overnight at $4^{\circ} \mathrm{C}$. Individual band patterns were compared by visual examination after electrophoresis in 1.5\% agarose gels, and representative strains (from each cheese at each sample time) that showed unique RAPD fingerprints were selected for further characterization. When necessary, additional RAPD experiments were performed to determine the similarity between isolates collected at various sample times or from different cheeses.

\section{Identification of Bacteria}

Cheese or environmental isolates that displayed a unique RAPD fingerprint were identified to the nearest known phylogenetic relative by partial nucleotide sequence analysis of the 16S rRNA gene (Baruzzi et al., 2000 ). One set of universal primers, $\mathrm{UF}_{1}\left(5^{\prime}\right.$-AGAGTTTGATCCTGGCTCAG- $3^{\prime}$ ) and $\mathrm{UR}_{1}$ (5'-GCTGGCACG TAGTTAGCC-3'), were used to amplify 520 bp from the $5^{\prime}$ end of the 16S rRNA gene by PCR. The reactions were performed in 50- $\mu \mathrm{l}$ volumes that contained 1.5 $\mathrm{m} M \mathrm{Mg}^{2+}, 0.4 \mathrm{~m} M$ dNTP blend, $1.75 \mathrm{U}$ of Expand high fidelity DNA polymerase (Roche Diagnostics, Indianapolis, IN), $1 \mu M$ of each oligonucleotide primer, and 5 $\mu \mathrm{l}$ of template DNA. Negative controls were prepared with sterile water as a substitute for template DNA. Samples were overlaid with $70 \mu \mathrm{l}$ of PCR-grade sterile mineral oil, then 40 PCR cycles were performed with the following parameters: 2 -min soak at $94^{\circ} \mathrm{C}$, then 30 
cycles of $15 \mathrm{~s}$ at $94^{\circ} \mathrm{C}, 1 \mathrm{~min}$ at $55^{\circ} \mathrm{C}$, and $1.5 \mathrm{~min}$ at $72^{\circ} \mathrm{C}$. The reaction was finished by incubation at $72^{\circ} \mathrm{C}$ for $7 \mathrm{~min}$ then stored overnight at $4^{\circ} \mathrm{C}$. The presence of amplicon was confirmed by electrophoresis in $1.5 \%$ agarose gels, then purified with a Bio-Rad Prep-a-Gene kit (Hercules, CA) and bidirectionally sequenced by fluorescent dideoxy chain termination on a Perkin Elmer Applied Biosystems automated DNA sequencer (model 373A). Nucleotide sequence similarity searches were performed using BLAST tools available through the National Institutes of Health Center for Biotechnology Information (www.ncbi.nlm.nih.gov) to determine the species from which each amplicon was most likely derived. In some cases, nucleotide sequence analysis of the $5^{\prime} 16 \mathrm{~S}$ rRNA gene fragment proved inconclusive, so a second set of universal primers ( $\mathrm{UF}_{2} 5^{\prime}$-GCACAAGCGGTGGAG-3'; and UR 2 5'-TTGTCACCGGCAGTCT-3') were used to amplify a 235-bp distal region of the $16 \mathrm{~S}$ rRNA gene. The PCR, nucleotide sequence determination, and homology searches were performed as described above.

\section{Sugar Fermentation Profiles of NSLAB}

The ability of selected NSLAB isolates to produce acid from different carbohydrates was determined with API 50 CHL test kits (bioMérieux, Hazelwood, Mo). The API test strips were prepared as recommended by the kit supplier and scored after incubation for $24 \mathrm{~h}$ at $30^{\circ} \mathrm{C}$. Test results were communicated to the bioMérieux technical service department, which used the phenotypic data to predict a species identity for each isolate.

\section{Sensory Evaluation and Statistics}

Trained sensory evaluation of cheese was performed at 3 and 6 mo by six to 10 experienced judges in a randomized blind design as described previously (Weimer et al., 1997). Cheeses were judged for qualities that included Cheddar flavor intensity $(1=$ none, $7=$ aged $)$, lipase/rancid flavor intensity $(1=$ none, $7=$ pronounced), off-flavor intensity ( $1=$ none, $7=$ pronounced $)$, and overall flavor preference $(1=$ dislike very much, $7=$ like very much). Statistical evaluation of cheese composition and sensory data was performed by ANOVA using Minitab software version 9.1 (Minitab Inc., State College, PA), and differences were declared to be significant when $P<0.05$.

\section{RESULTS}

\section{Cheese Composition}

Mean percentages of moisture, salt, salt-in-moisture, and fat in experimental reduced-fat Cheddar and Colby
Table 1. Mean composition of Cheddar and Colby cheeses prepared in the study. ${ }^{1}$

\begin{tabular}{lrr}
\hline Component & \multicolumn{1}{l}{ Cheddar } & \multicolumn{1}{l}{ Colby } \\
\hline Moisture (\%) & $48.39 \pm 0.46^{\mathrm{a}}$ & $49.35 \pm 0.26^{\mathrm{b}}$ \\
Salt $(\%)$ & $1.50 \pm 0.03^{\mathrm{a}}$ & $1.60 \pm 0.05^{\mathrm{b}}$ \\
Salt-in-moisture (\%) & $3.11 \pm 0.09^{\mathrm{a}}$ & $3.23 \pm 0.01^{\mathrm{a}}$ \\
Fat (\%) & $12.33 \pm 0.10^{\mathrm{a}}$ & $12.25 \pm 0.16^{\mathrm{a}}$ \\
Cheese pH & & \\
Press & $5.09 \pm 0.04^{\mathrm{a}}$ & $5.12 \pm 0.03^{\mathrm{a}}$ \\
$2 \mathrm{wk}$ & $5.07 \pm 0.10^{\mathrm{a}}$ & $5.21 \pm 0.02^{\mathrm{b}}$ \\
$1 \mathrm{mo}$ & $5.12 \pm 0.04^{\mathrm{a}}$ & $5.27 \pm 0.01^{\mathrm{b}}$ \\
$2 \mathrm{mo}$ & $5.11 \pm 0.02^{\mathrm{a}}$ & $5.30 \pm 0.01^{\mathrm{b}}$ \\
$3 \mathrm{mo}$ & $5.20 \pm 0.03^{\mathrm{a}}$ & $5.40 \pm 0.03^{\mathrm{b}}$ \\
$6 \mathrm{mo}$ & $5.25 \pm 0.01^{\mathrm{a}}$ & $5.60 \pm 0.05^{\mathrm{b}}$ \\
Total lactate & & \\
Day 1 & $1.51 \pm 0.11^{\mathrm{a}}$ & $1.48 \pm 0.02^{\mathrm{a}}$ \\
$1 \mathrm{mo}$ & $1.88 \pm 0.02^{\mathrm{a}}$ & $1.60 \pm 0.03^{\mathrm{b}}$ \\
$3 \mathrm{mo}$ & $1.97 \pm 0.01^{\mathrm{a}}$ & $1.67 \pm 0.02^{\mathrm{b}}$ \\
$4 \mathrm{mo}$ & $1.94 \pm 0.02^{\mathrm{a}}$ & $1.66 \pm 0.02^{\mathrm{b}}$ \\
\hline
\end{tabular}

${ }^{1}$ Cheese composition was not significantly altered by addition of Lactobacillus casei adjunct, so values listed for each cheese type represent product made with and without the adjunct. Means with the same superscript letter in the same row were not significantly different from one another $(P>0.05)$.

cheeses are presented in Table 1 . As expected, the washed Colby cheese contained significantly $(P<0.05)$ less residual lactose at press, and had a significantly higher $\mathrm{pH}$ and a significantly lower total lactate content (and thus a significantly lower lactic acid to moisture ratio) throughout ripening versus the nonwashed Cheddar cheese. Experimental Colby also had significantly higher average moisture and salt contents than the Cheddar cheese, but mean percentages of salt-in-moisture or fat in each cheese type were not significantly different (Table 1).

The addition of $L b$. casei LILA did not significantly affect $(P>0.05)$ any of the compositional attributes shown in Table 1, but cheeses made with the adjunct did have a significantly $(P<0.05)$ lower D-lactate content than control cheeses at 1,2 , and 4 mo of age. The percentage of D-lactate in the total lactate content of Cheddar and Colby cheese made with $L b$. casei LILA at $\mathrm{d} 1$, and $1,2,3$ and 4 mo of age was $2.8,2.9,18.6$, 23.6 , and $28.8 \%$, respectively. Levels for control cheeses at the same time points were $2.7,7.8,30.4,21.4$, and $33.3 \%$, respectively.

\section{Sensory Scores}

The ANOVA of sensory scores collected at 90 and 180 $\mathrm{d}$ by experienced judges in a randomized blind design showed neither cheese type nor adjunct addition had a significant effect $(P>0.05)$ on Cheddar flavor intensity, lipase/rancid flavor intensity, off-flavor intensity, overall flavor preference, or body/texture preference (data not shown). 


\section{Microbiological Counts}

No colonies were detected on Rogosa agar from microbiological samples collected from the processing plant immediately before cheese manufacture. Plate counts on Elliker agar were also negative for most areas, but $6.8 \times 10^{2}$ cfu were recovered from the floor drain between cheese vats, and $<10$ colonies were isolated from the lab bench and stirrer motor. Similar analysis of pasteurized milk samples yielded no colonies on Rogosa agar, while counts on Elliker agar detected $2.9 \times 10^{2}$ $\mathrm{cfu} / \mathrm{ml}$.

Enumeration of starter and nonstarter bacteria in experimental reduced-fat cheeses showed all cheeses contained approximately $2.0 \times 10^{9}$ starter cfu/g at pressing, and that the number of viable starter bacteria declined about one order of magnitude during the 6 mo ripening period (Table 2). No NSLAB were detected on Rogosa agar plates from d 1 Cheddar or Colby cheeses that did not contain $L b$. casei LILA adjunct, but numbers of adventitious lactobacilli in these cheeses was greater than $10^{4} \mathrm{cfu} / \mathrm{g}$ by 4 mo (Table 2). Lactobacillus spp. counts in cheeses that contained Lb. casei LILA adjunct were greater than $10^{6} \mathrm{cfu} / \mathrm{g}$ at press and remained above $10^{7} \mathrm{cfu} / \mathrm{g}$ throughout the ripening period.

\section{Identification of Environmental and Cheese Isolates}

The RAPD was performed on more than 320 individual colonies collected from environmental samples and from Cheddar and Colby cheese extracts plated on Rogosa or Elliker agar after pressing (d 1), and after 2, 4, and 6 mo of ripening. At every sample point or time, unique strains present in those samples were identified by visual examination of RAPD fingerprints (Figures 1 and 2). Representative strains for each unique DNA fingerprint were then selected and identified to the nearest taxonomic relative by nucleotide sequence analysis of 16S rRNA gene fragments. As noted in the previous section, no colonies were detected on Rogosa agar from environmental samples or pasteurized cheese milk, and no facultatively heterofermentative lactobacilli were identified among the strains isolated from
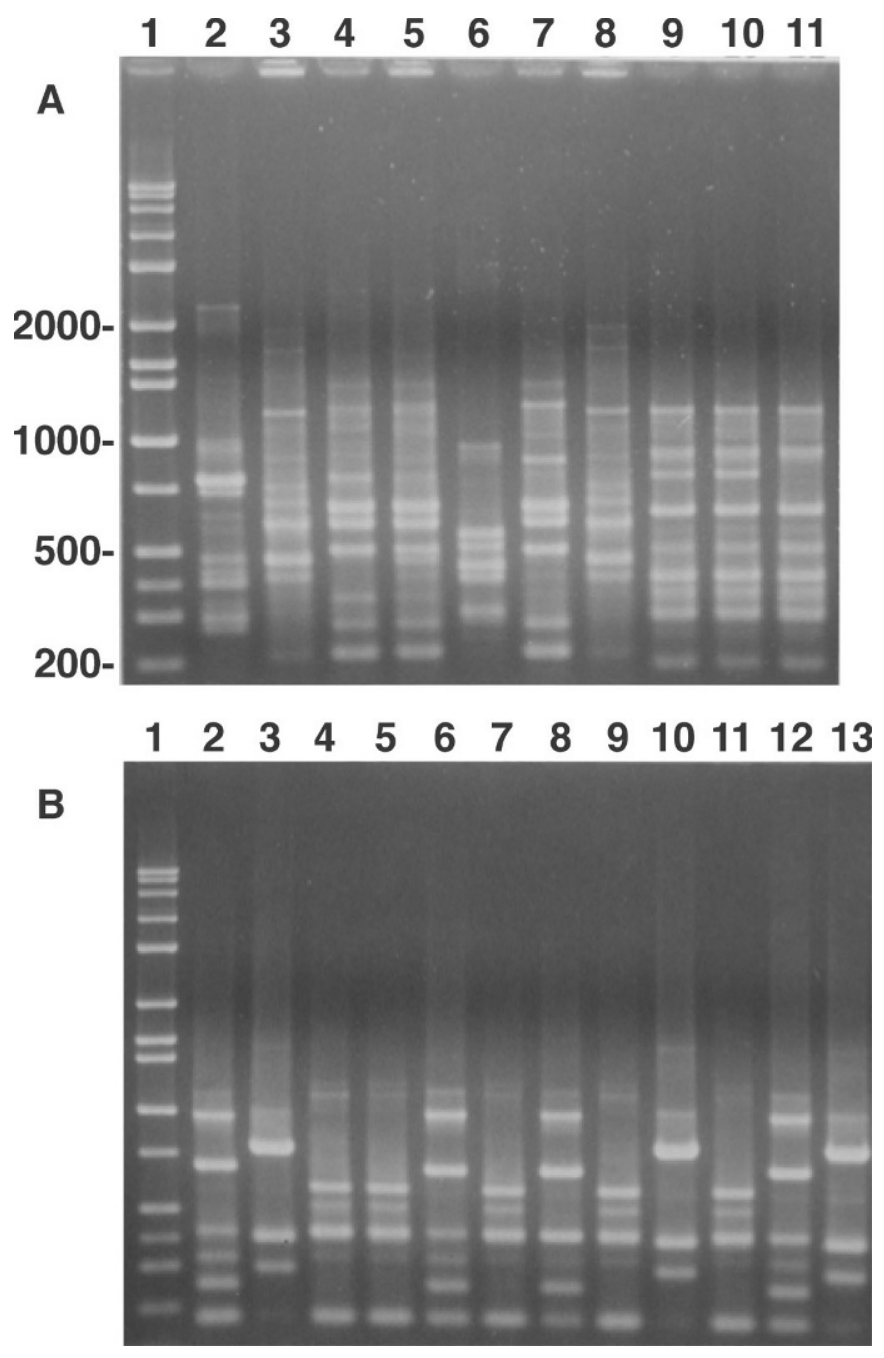

Figure 1. Agarose gel electrophoresis of randomly amplified polymorphic DNA (RAPD) from environmental bacterial isolates collected on Elliker agar. Panel A shows RAPD patterns for strains isolated from environmental surface swabs before cheese making, whereas panel B shows RAPD profiles for isolates obtained from pasteurized cheese milk prior to starter inoculation. Lane 1 in each panel contains DNA fragment size standards.

either source on Ellikers agar. Instead, representative strains of bacteria collected from environmental surface swabs prior to cheese making (Figure 1A) included $B a$ -

Table 2. Mean total number (cfu/g) of viable Lactococcus lactis starter and lactobacilli (nonstarter alone or nonstarter plus Lactobacillus casei LILA adjunct) in experimental cheeses during ripening.

\begin{tabular}{|c|c|c|c|c|c|c|c|c|}
\hline \multirow{2}{*}{$\begin{array}{l}\text { Sample } \\
\text { time }\end{array}$} & \multicolumn{2}{|c|}{ Cheddar } & \multicolumn{2}{|c|}{ Cheddar + LILA } & \multicolumn{2}{|c|}{ Colby } & \multicolumn{2}{|c|}{ Colby + LILA } \\
\hline & Starter & Lactobacilli & Starter & Lactobacilli & Starter & Lactobacilli & Starter & Lactobacilli \\
\hline Day 1 & $2.0 \times 10^{9}$ & $<10$ & $1.8 \times 10^{9}$ & $8.4 \times 10^{6}$ & $2.2 \times 10^{9}$ & $<10$ & $2.0 \times 10^{9}$ & $4.0 \times 10^{6}$ \\
\hline $2 \mathrm{mo}$ & $6.1 \times 10^{8}$ & $1.6 \times 10^{4}$ & $5.2 \times 10^{8}$ & $6.1 \times 10^{7}$ & $6.9 \times 10^{8}$ & $6.1 \times 10^{3}$ & $1.1 \times 10^{9}$ & $6.3 \times 10^{7}$ \\
\hline $4 \mathrm{mo}$ & $3.5 \times 10^{8}$ & $5.8 \times 10^{4}$ & $3.7 \times 10^{8}$ & $5.6 \times 10^{7}$ & $5.6 \times 10^{8}$ & $3.5 \times 10^{5}$ & $5.4 \times 10^{8}$ & $9.2 \times 10^{7}$ \\
\hline $6 \mathrm{mo}$ & $1.0 \times 10^{8}$ & $1.3 \times 10^{7}$ & $2.0 \times 10^{8}$ & $7.0 \times 10^{7}$ & $1.6 \times 10^{8}$ & $5.5 \times 10^{5}$ & $1.7 \times 10^{8}$ & $5.0 \times 10^{8}$ \\
\hline
\end{tabular}



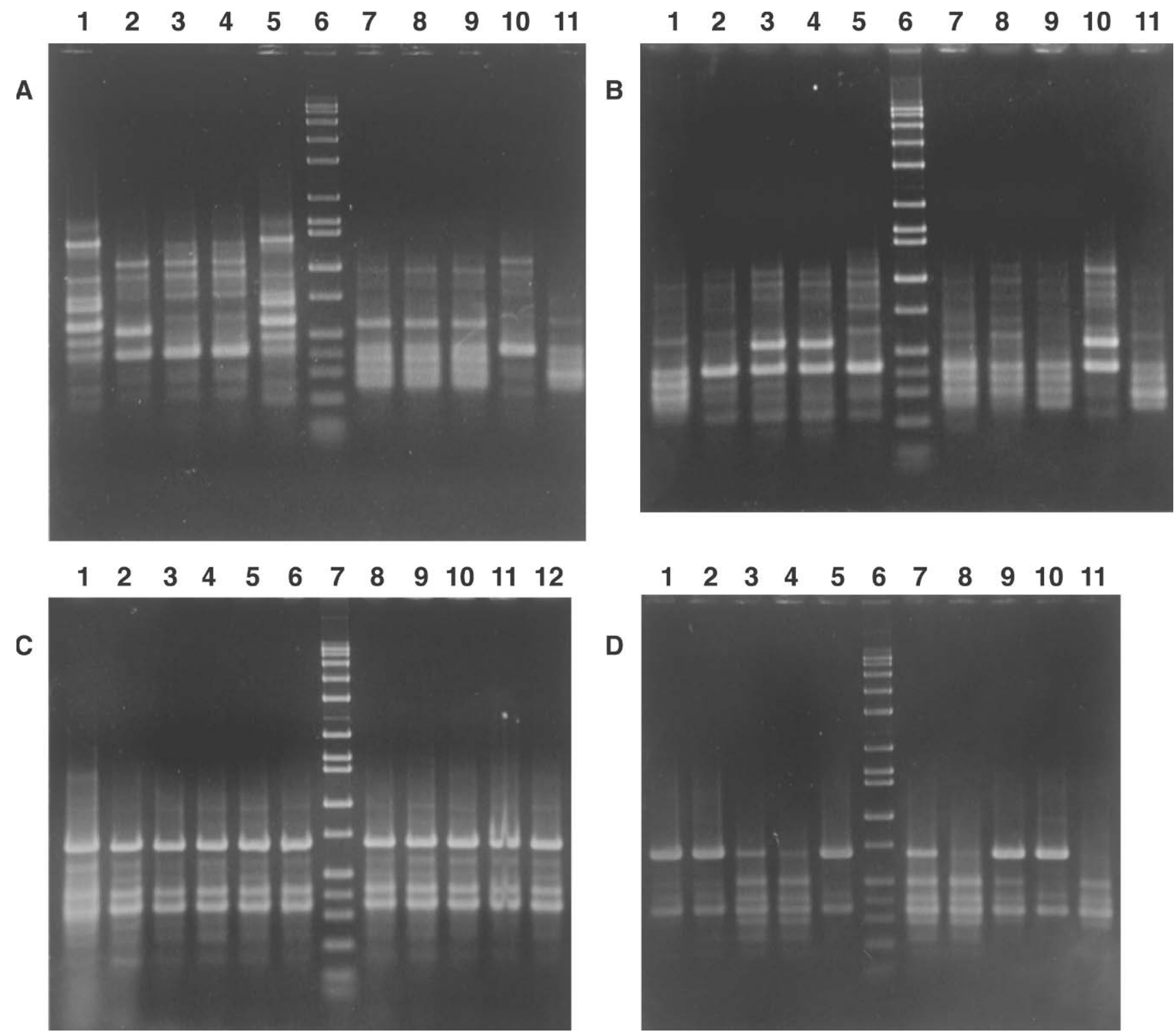

Figure 2. Agarose gel electrophoresis of randomly amplified polymorphic DNA (RAPD) from nonstarter lactic acid bacteria (NSLAB) isolated on Rogosa agar from extracts of ripened reduced-fat Cheddar or Colby cheese. Panels A and B show RAPD patterns for NSLAB isolated from 2-mo-old Cheddar and Colby cheese, respectively. Panel C shows RAPD profiles for NSLAB collected from 2-mo-old Cheddar made with Lactobacillus casei LILA adjunct, with the adjunct RAPD profile shown in lane 1. Panel D shows RAPD patterns for NSLAB collected from 4-mo-old Colby cheese made with L. casei LILA. Lane 6 in panels A, B, and D contain DNA fragment size standards, which are also present in lane 7 of panel C.

cillus licheniformis, Enterococcus durans, Escherichia coli, and Klebsiella sp. Isolates obtained from pasteurized cheese milk before starter inoculation (Figure 1B) included one strain of Lc. lactis spp. lactis and several strains of Streptococcus spp. phylogenetically related to either $S$. salivarius or $S$. bovis.

Characterization of NSLAB isolates from each cheese by RAPD and16S rDNA sequencing showed NSLAB populations in both types of control cheeses were dominated by Lb. curvatus and Lb. casei (Tables 3 and 4). By
4 mo, NSLAB isolates from control reduced-fat Cheddar cheese were all identified as $L b$. casei, and this species was also the only one found at 6 mo (Table 3 ). In contrast, 4-mo-old control reduced-fat Colby contained a variety of NSLAB species including $L b$. curvatus, $L b$. casei, and Enterococcus spp., and species heterogeneity was also noted in 6-mo-old cheese (Table 4). Addition of $L b$. casei LILA appeared to reduce NSLAB species and strain heterogeneity in ripening Colby and young Cheddar. As shown in Figure 2, the RAPD profile of the 
Table 3. Population dynamics of Lactococcus lactis ssp. cremoris (Lc. cremoris), Lactococcus lactis spp. lactis (Lc. lactis), and Lactobacillus $(L b$.$) spp. starter and nonstarter bacteria in reduced-fat Cheddar cheese made with or without L b$. casei LILA adjunct. ${ }^{1}$

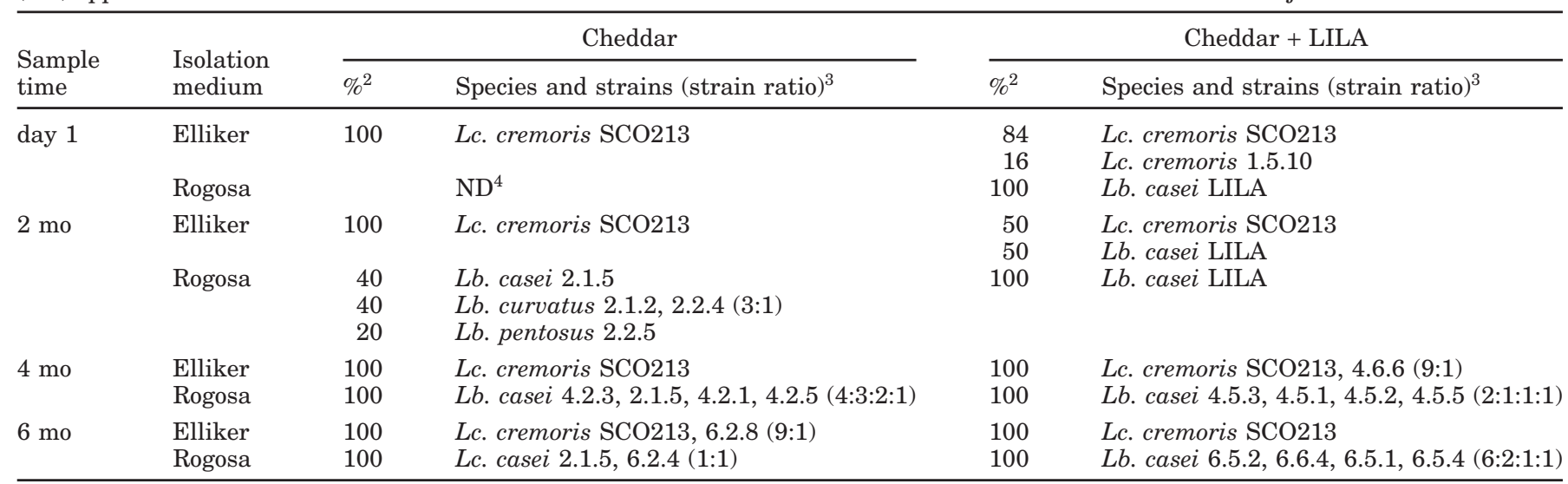

\footnotetext{
${ }^{1}$ As determined by randomly amplified polymorphic DNA profile, partial nucleotide sequence analysis of the 16S rRNA gene, and API 50 CHL carbohydrate fermentation patterns.

${ }^{2}$ Of 10 individual isolates collected at random from each growth medium at each sampling time.

${ }^{3}$ Representative strain designation (relative ratio of individual strains isolated within a particular species). Strains recovered at more than one ripening time are identified by repeated use of the first designation assigned to the strain.

${ }^{4}$ Not determined (no colonies detected on agar plates).
}

adjunct was the only pattern observed among NSLAB isolates from $\mathrm{d} 1$ and 2-mo-old cheeses (Figure 2C). Although the adjunct was not detected in 4- or 6-moold reduced-fat Cheddar and Colby cheeses, both cheese types yielded fewer strains of wild $L b$. casei than did their respective control cheeses (Tables 3 and 4).

Interestingly, RAPD patterns and sugar fermentation profiles indicated that the dominant strains of $L b$. casei in each cheese appeared to be most affected by adjunct treatment and not cheese variety. In control cheese, for example, $L b$. casei isolate 2.1.5 was recovered from 2-, 4-, and 6-mo-old Cheddar and from 4- and 6-mo-old Colby cheese, but it was not detected in cheese made with $L b$. casei LILA adjunct (Tables 3 and 4). Conversely, $L b$. casei isolates 6.5.2 and 6.5.4 were recovered from 6-mo-old Cheddar and Colby cheeses made

Table 4. Population dynamics of Lactococcus lactis spp. cremoris (Lc. cremoris), Lactococcus lactis spp. lactis (Lc. lactis), and Lactobacillus (Lb.) spp. starter and nonstarter bacteria in reduced-fat Colby cheese made with or without Lb. casei LILA adjunct. ${ }^{1}$

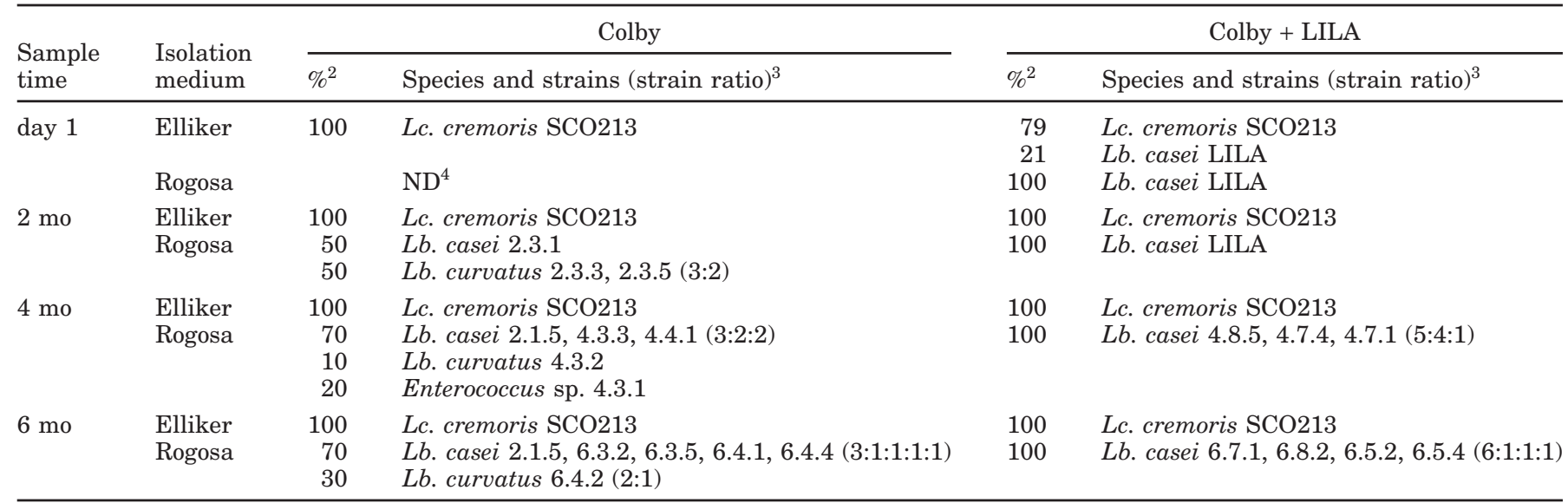

\footnotetext{
${ }^{1}$ As determined by randomly amplified polymorphic DNA profile, partial nucleotide sequence analysis of the $16 \mathrm{~S}$ rRNA gene, and API 50 CHL carbohydrate fermentation patterns.

${ }^{2}$ Of 10 isolates collected from each growth medium at each sampling time.

${ }^{3}$ Representative strain designation (relative ratio of individual strains isolated within a particular species). Strains recovered at more than one ripening time are identified by repeated use of the first designation assigned to the strain.

${ }^{4}$ Not determined (no colonies detected on plate counts).
} 
with $L b$. casei LILA, but were not found in control cheeses.

\section{Carbohydrate Utilization by NSLAB}

Analysis of carbohydrate fermentation patterns by 39 dominant NSLAB isolates collected from 2- (8 strains), 4- (16 strains), or 6- (15 strains) mo-old, reduced-fat Cheddar or Colby cheese showed all isolates fermented galactose, glucose, fructose, mannose, and $\mathrm{N}$-acetyl glucosamine. Lactose, esculine, and tagatose were also utilized by at least $75 \%$ of the NSLAB isolates collected for characterization from 2-, 4-, or 6-mo-old cheeses, while ribose was fermented by 63 to $75 \%$ of these strains, depending on the sampling time. Finally, the ability to ferment mannitol, turanose, cellobiose, maltose, trehalose, and melezitose was slightly more prevalent in dominant strains from 4- and 6-mo-old cheese (50 to $75 \%$ positive, depending on the sampling time) than 2-mo samples (38 to $50 \%$ positive).

Phenotypic identification of dominant NSLAB isolates through API 50 CHL carbohydrate fermentation profiles showed little consensus with $16 \mathrm{~S}$ rDNA sequence data, with taxonomic agreement only noted for 12 of 39 strains (31\%) analyzed by both methods. Most of the discrepancy between these methods was due to 19 isolates (49\% of total) that had metabolic traits most akin to $L b$. curvatus, but whose closest phylogenetic relative by $16 \mathrm{~S}$ rDNA sequence analysis was $L b$. casei.

\section{DISCUSSION}

All bacterial-ripened cheeses contain NSLAB that enter cheese through processing equipment or milk and grow to high numbers during ripening (Beresford et al., 2001). Although NSLAB can have a significant effect on flavor development, little is known about the factors that influence the growth and composition of their populations. As a result, the types and numbers of NSLAB present in cheese remain largely a matter of chance. Nonetheless, the knowledge that NSLAB influence cheese quality indicates technologies to control NSLAB populations during ripening would impart greater uniformity to the overall quality of Cheddar and other bacterial-ripened cheeses.

One of the most promising strategies to control NSLAB populations is to employ well-characterized Lactobacillus spp. adjunct cultures that suppress the emergence of wild NSLAB (Broome et al., 1990a; Crow et al., 2001). Cheese is a dynamic environment, however, and the effectiveness of adjunct technology may be limited by differences in cheese composition or manufacturing and ripening regimens. Colby and Cheddar cheeses are commonly manufactured with identical strains of Lc. lactis starter, but Colby cheese is a washed, stirred-curd variety of Cheddar, and this treatment produces significant differences in the cheese microenvironment (Table 1). Because the intrinsic properties of Colby are less restrictive to microbial growth than those of Cheddar, it was our hypothesis that the environment in the former cheese would accommodate a greater diversity of NSLAB species and strains than the latter. To investigate this hypothesis, we examined NSLAB population dynamics in reduced-fat Cheddar and Colby cheese, and studied the effect of $L b$. casei LILA on NSLAB population dynamics in each cheese.

Results showed the NSLAB biota in both cheeses changed over time, but NSLAB populations in Colby cheese were more heterogeneous for a longer period of ripening than those of Cheddar made in the same processing facility (Tables 3 and 4). Addition of the Lb. casei adjunct to Cheddar or Colby cheese did not influence sensory qualities or important compositional attributes, but it did appear to limit the NSLAB species and strain heterogeneity in both cheeses. In addition, even though the adjunct was not detected in 4- or 6 moold reduced-fat Cheddar and Colby cheeses, the dominant strains of $L b$. casei in each cheese appeared to be most affected by adjunct treatment and not cheese variety. The reasons for these observations are unknown, but they do support the hypothesis that adjunct cultures can help to control cheese NSLAB composition during ripening.

Data from this study also indicated that phenotypic identification of cheese NSLAB may be problematic, and similar observations have been noted by other researchers (Liu et al., 1988; Nigatu, 2000). The most common discrepancy between phenotypic and $16 \mathrm{~S}$ rDNA sequence data in this study was due to isolates that had sugar fermentation profiles most like $L b$. curvatus, but whose $16 \mathrm{~S}$ rDNA sequence was most closely related to $L b$. casei. Because $L b$. curvatus and $L b$. casei are mesophilic, facultatively heterofermentative species with relatively similar sugar fermentation profiles (Kandler and Weiss, 1986), it is not surprising that efforts to identify these species through phenotypic data may lead to confusion.

The substrates used by NSLAB for growth in cheese have been the subject of considerable research interest and conjecture (Fryer, 1969). Previous workers have shown NSLAB can derive energy from compounds such as lactic acid, citric acid, carbohydrate moieties from glycoproteins, fatty acids, glycerol, and amino acids (Fryer, 1969; Thomas, 1986; Williams et al., 2000). Evidence also suggests that starter autolysis may be an important source of ribose and other nutrients for NSLAB growth (Thomas, 1987; Rapposch et al., 1999). Nonetheless, the substrates required by NSLAB to at- 
tain final populations levels of $10^{7}$ to $10^{9} \mathrm{cfu} / \mathrm{g}$ in ripening cheese have not been conclusively identified. Examination of carbohydrate fermentation patterns for NSLAB strains isolated in this study also did not reveal any obvious differences in the sugar utilization profiles for strains isolated at different ripening periods. Although the ability to ferment some sugars was more prevalent in dominant strains from 4- and 6-mo-old cheese than 2-mo samples, the differences were not striking (50 to $75 \%$ vs. 38 to $50 \%$ positive) and could have simply been due to variation in the sample size.

\section{CONCLUSIONS}

The dynamic and complex nature of NSLAB populations in Cheddar cheese is a likely source of quality defects and inconsistencies, so technologies to control NSLAB populations during ripening should provide greater uniformity in overall cheese quality. Lactobacillus spp. adjuncts are a promising tool for this purpose, but their efficacy is challenged by the ecological diversity that results from differences in cheese manufacturing and ripening protocols, and in overall cheese composition. To overcome these challenges, additional research is needed to understand the impact of the cheese microenvironment on growth and dominance of NSLAB species and strains.

\section{ACKNOWLEDGMENTS}

The authors thank Rebekah Allen, Kristen Anderson, Brie-Ann McKernan, Melinda Moss, Beatriz Rodriguez, and Ann Stuhlman for technical assistance, and Charlotte Brennand for help with statistics. This work was supported by Dairy Management, Inc., through the Western Dairy Center and the Wisconsin Center for Dairy Research, and by the Utah Agricultural Experiment Station.

\section{REFERENCES}

Baruzzi, F., M. Morea, A. Matarante, and P. S. Cocconcelli. 2000. Changes in the Lactobacillus community during Ricotta forte cheese natural fermentation. J. Appl. Microbiol. 89:807-814.

Bassam, B. J., G. Caetano-Anolles, and P. M. Gresshoff. 1992. DNA amplification fingerprinting of bacteria. Appl. Microbiol. Biotechnol. 38:70-76.

Beresford, T. P., N. A. Fitzsimons, N. L. Brennan, and T. M. Cogan. 2001. Recent advances in cheese microbiology. Int. Dairy J. 11:259-274.

Berthier, F., E. Beuvier, A. Dasen, and R. Grappin. 2001. Origin and diversity of mesophilic lactobacilli in Comté cheese, as revealed by PCR with repetitive and species-specific primers. Int. Dairy J. 11:293-305.

Broadbent, J. R., C. J. Oberg, and L. Wei. 1998. Characterization of the Lactobacillus helveticus groESL operon. Res. Microbiol. 149:247-253.

Broome, M. C., D. A. Krause, and M. W. Hickey. 1990a. The isolation and characterization of lactobacilli from Cheddar cheese. Aust. J. Dairy Technol. 45:60-66.
Broome, M. C., D. A. Krause, and M. W. Hickey. 1990b. The use of non-starter lactobacilli in Cheddar cheese manufacture. Aust. J. Dairy Technol. 45:67-73.

Crow, V., B. Curry, and M. Hayes. 2001. The ecology of non-starter lactic acid bacteria (NSLAB) and their use as adjuncts in New Zealand Cheddar. Int. Dairy J. 11:275-283.

Fitzsimons, N. A., T. M. Cogan, S. Condon, and T. Beresford. 1999. Phenotypic and genotypic characterization of non-starter lactic acid bacteria in mature Cheddar cheese. Appl. Environ. Microbiol. 65:3418-3426.

Fitzsimons, N. A., T. M. Cogan, S. Condon, and T. Beresford. 2001. Spatial and temporal distribution of non-starter lactic acid bacteria in Cheddar cheese. J. Appl. Microbiol. 90:600-606.

Fox, P. F., J. Law, P. L. H. McSweeney, and C. M. Lynch. 1998. Significance of non-starter lactic acid bacteria in cheddar cheese. Aust. J. Dairy Technol. 53:83-89.

Fox, P. F., J. Law, P. L. H. McSweeney, and J. Wallace. 1993. Biochemistry of cheese ripening. Pages 389-438 in Cheese: Chemistry, Physics and Microbiology. Vol. 1. 2nd ed. P. F. Fox, ed. Chapman and Hall, London, England.

Frohlich-Wyder, M. T., H. P. Bachmann, and M. G. Casey. 2002. Interaction between propionibacteria and starter/nonstarter lactic acid bacteria in Swiss-type cheeses. Lait 82:1-15.

Fryer, T. F. 1969. Microflora of Cheddar cheese and its influence on cheese flavour. Dairy Sci. Abstr. 31:471-490.

Johnson, M. E. 2001. Cheese products. Pages 345-384 in Applied Dairy Microbiology. 2nd ed. E. H. Marth and J. L. Steele, ed. Marcell Dekker, Inc., New York.

Johnson, M. E., B. A. Riesterer, and N. F. Olsen. 1990. Influence of nonstarter bacteria on calcium lactate crystallization on the surface of Cheddar cheese. J. Dairy Sci. 73:1145-1149.

Jordan, K. N., and T. M. Cogan. 1993. Identification and growth of non-starter lactic acid bacteria in Irish Cheddar cheese. Irish J. Agric. Food Res. 32:47-55.

Kandler, O., and N. Weiss. 1986. Genus Lactobacillus. Pages 12091234 in Bergey's Manual of Systematic Bacteriology. Vol. 2. 9th ed. P. H. A. Sneath, N. S. Mair, M. E. Sharpe, and J. G. Holt, ed. Williams and Wilkins, Baltimore.

Layele, L. C., R. E. Simard, B.-H. Lee, and R. A. Holly. 1990. Quality attributes of Cheddar cheese containing added lactobacilli. J. Food Sci. 55:114-118.

Liu, M.-L., J. K. Kondo, M. B. Barnes, and D. T. Bartholomew. 1988. Plasmid-linked maltose utilization in Lactobacillus ssp. Biochimie 70:351-355.

Lynch, C. M., D. D. Muir, J. M. Banks, P. L. H. McSweeney, and P. F. Fox. 1999. Influence of adjunct cultures of Lactobacillus paracasei ssp. paracasei or Lactobacillus plantarum on Cheddar cheese ripening. J. Dairy Sci. 82:1618-1628.

McSweeney, P. L. H., E. M. Walsh, P. F. Fox, T. M. Cogan, F. D. Durain, and M. Castelo-Gonzalez. 1994. A procedure for the manufacture of Cheddar cheese under controlled bacteriological conditions and the effect of adjunct lactobacilli on cheese quality. Irish J. Agric. Food Res. 33:183-192.

Naylor, J., and M. E. Sharpe. 1958. Lactobacilli in Cheddar cheese. II. Duplicate cheeses. J. Dairy Res. 25:421-430.

Nigatu, A. 2000. Evaluation of numerical analyses of RAPD and API $50 \mathrm{CH}$ patterns to differentiate Lactobacillus plantarum, Lact. fermentum, Lact. sake, Lact. parabuchneri, Lact. gallinarum, Lact. casei, Weisella minor and related taxa isolated from kocho and tef. J. Appl. Microbiol. 89:969-978.

Peterson, S. D., and R. T. Marshall. 1990. Nonstarter lactobacilli in Cheddar cheese: A review. J. Dairy Sci. 73:1395-1410.

Rapposch, S., F. Eliskases-Lechner, and W. Ginzinger. 1999. Growth of facultatively heterofermentative lactobacilli on starter cell suspensions. Appl. Environ. Microbiol. 65:5597-5599.

Reiter, B., T. F. Fryer, A. Pickering, H. R. Chapman, R. C. Lawrence, and M. E. Sharpe. 1967. The effect of the microbial flora on the flavour and free fatty acid composition of Cheddar cheese. J. Dairy Res. 34:257-272.

Ryan, M. P., R. P. Ross, and C. Hill. 2001. Strategy for manipulation of cheese flora using combinations of lacticin 3147-producing and resistant cultures. Appl. Environ. Microbiol. 67:2699-2704. 
Sherwood, I. R. 1939. The bacterial flora of New Zealand Cheddar cheese. J. Dairy Res. 10:449-454.

Somers, E. B., M. E. Johnson, and A. C. L. Wong. 2001. Biofilm formation and contamination of cheese by nonstarter lactic acid bacteria in the dairy environment. J. Dairy Sci. 84:1926-1936.

Swearingen, P. A., D. J. O'Sullivan, and J. J. Wartheson. 2001. Isolation, characterization, and influence of native nonstarter lactic acid bacteria on Cheddar cheese quality. J. Dairy Sci. 84:50-59.

Thomas, T. D. 1986. Oxidative activity of bacteria from Cheddar cheese. N.Z. J. Dairy Sci. Technol. 21:37-47.

Thomas, T. D. 1987. Cannibalism among bacteria found in cheese. N.Z. J. Dairy Sci. Technol. 22:215-219.
Weimer, B., B. Dias, U. Madhavi, J. Broadbent, C. Brennand, J. Jaegi, M. Johnson, F. Milani, J. Steele, and D. V. Sisson. 1997. Influence of $\mathrm{NaCl}$ and $\mathrm{pH}$ on intracellular enzymes that influence Cheddar cheese ripening. Lait 77:383-398.

Williams, A. G., and J. M. Banks. 1997. Proteolytic and other hydrolytic enzyme activities in non-starter lactic acid bacteria isolated from Cheddar cheese manufactured in the United Kingdom. Int. Dairy J. 7:763-774.

Williams, A. G., S. E. Withers, and J. M. Banks. 2000. Energy sources of non-starter lactic acid bacteria isolated from Cheddar cheese. Int. Dairy J. 10:17-23. 